\title{
THE NUMERICAL ANALYSIS OF SELECTED DEFECTS IN FORGING PROCESSES
}

\author{
Aneta Lukaszek-Solek, Sylwia BednareK*, Lukasz LiSiecki, Piotr Skubisz \\ AGH University of Science and Technology, al. Mickiewicza 30, 30-059 Krakow, Poland \\ *Corresponding author: syb@agh.edu.pl
}

\begin{abstract}
High demands made by customers and the need to reduce production costs while maintaining high quality of products brings the necessity to include specialized models and criteria in the numerical analysis of forging processes. The latest approaches offered by commercial software manufacturers do not include comprehensive analysis of defects. In many cases is necessary to include user subroutines dedicated to specific forging operations. Interdisciplinary knowledge allows selection of creation of forecasting technique typical for analyzed forging process. The main purpose of the review article is to show the latest tools, their modifications and extensions for predicting defects typical for forging processes and often observed in the industrial process using FEM modelling. The authors showed that additional parameters or functions can support the conventional stress and strain parameters to extend the possibilities of interpretation, e.g. by means of postprocessor subroutines. Various forging processes, typical defects and optimized method of their forecasting were presented. The research methodology was a combination of numerical modelling, laboratory tests and analysis of industrial processes.
\end{abstract}

Key words: Numerical modelling, Forging, Defects, Postprocessing subroutines

\section{INTRODUCTION}

Technological development and growing performance expectations these days force quality attitude from the forging industry, which needs to be implemented at the very initial stage of design. Tendency of weight reduction calling for high-strength steels and near-net forging results in sophisticated geometries to be forged under severe work conditions producing low workability. One of the cost-effective contemporary tool supporting the design of forging technology is numerical modelling. State of art in computer codes for prediction of the metal behavior during deformation gives high credits to computer simulation, which allows significant reduction of research and development costs. On the other hand, the method prevailing in this field, finite element method (FEM) has some limitations, for instance, the results are indirectly applicable as some of the defects can only be recognized by use of auxiliary criteria for interpretation of the simulation results. The numerical methods eliminate restrictions and project limitations resulting from the lack of knowledge about the influence exerted by process conditions upon the material behaviour. The thermomechanical simulation of the forging process makes it possible to determine the local distributions of the state of strain, stress, and also temperature (Bednarek et al., 2012; Łukaszek-Sołek, 2014; Perez, 2018). The information obtained this way is sufficient for determining parameters, which guarantee the possibility of the process conducting and a product having the required quality (Guo et al., 2018; Saad et al., 2018). Numerical modelling in the case of the designing of a new forging or perfecting the one applied till now aims at predicting the manner of material flow, the analyzing of the impression die filling, determining of the areas of the possible defects formation, and also optimizing the dimensions of an initial material (Gao et al., 2019; He et al., 2017; 
Lisiecki \& Skubisz, 2015; Skripalenko et al., 2019). A variety of metal flow defects is observed, eg. laps, cold shuts, flow through defects, under filling, ductile fractures and metal behaviour patterns. These defects indicate potential hazard of failure caused by flow instability or inappropriate grain flow. In order to detect these metal flow defects conventional analysis of standard parameters such as stress, strain, displacement and temperature is often insufficient. Thus, additional parameters or functions can support the conventional stress and strain parameters to extend the possibilities of interpretation, e.g. by means of postprocessor subroutines (Lisiecki et al., 2015; Lisiecki \& Skubisz, 2016; Vlasov et al., 2016). Also traditional approach for modelling of ductile fracture indication is of limited use in case of instability of metal flow, which does not produce apparent visually detectable defects. Supplement to standard and user-defined functions of commercial codes are coefficients combining auto-calculated parameters, which make it possible to interpret the indication with accordance to one's needs, for example relative density for porous materials, coefficients for closing pores in ingots, surface representation, abrasive die wear factor or thermal parameters (Wojtaszek \& Bednarek, 2011; Chyła et al., 2011; Skubisz et al., 2008a; Petrov et al., 2016; Hawryluk et al., 2018; Skubisz et al., 2012; Stebunov et al. 2011). Altogether, they form a versatile design and diagnostics tool to be used in determination and optimization of forging process parameters.

Newer developments in computing technology and reduction in the associated costs are presently extending the circle of potential users and applications of the numerical modelling of metal forming processes. To the simulation of complex forming parts we can use many commercial finite element computer programs, for example: ADINA, FORGE ${ }^{\circledR} \mathrm{NxT}$, MSC Marc, Simufact Forming, QForm (Bramley \& Mynors, 2000). The authors of the publication present on the possibilities of defects prediction in forging processes based on numerical simulations in the QForm software.

The purpose of this work is to present and verify new techniques for predicting defects in forging processes with support of FEM modelling. Both solutions - techniques proposed by software producers as well as methods developed on the basis of process parameters obtained in laboratory tests were verified. Various forging processes, typical defects and optimized method of their forecasting were presented.
This is particularly important for design of new forging processes, optimization of the existing technologies when the large number of factors affecting the correctness of the forging process as well as their interaction makes very difficult to analyze the die forging processes.

The aim of this work is development of the 3D numerical model capable to simulate the laser cladding of bioactive glass coatings on ultrafine-grained metallic substrates. Model can predict the stressstrain and temperature distributions during the processing.

\section{NUMERICAL MODELLING OF FORGING DEFECTS}

The prediction of metal flow with high accuracy during forging processes enables to simulate owing to the high quality of the used algorithms in the software based on FEM. This approach allows reduction of costs of the trial-error sampling, not only in the implementation of new technology but also the modernization of existing technology especially in the field of complex-shaped and extremely complex-shaped forging elements (Alimov et al., 2018; Ellinghausen, 2013). The commercial software allows to conduct a number of simulations of the forging processes in order to assess the geometry of the deformation zone. The material flow kinematics in the aspect of filling of die cavity, the possible flow defects, and also the state of mean stresses with the domination of compressive stresses are taking under consideration. The high agreement of the simulation results with the real industrial process results, especially taking into consideration forging defects, should confirm the validity of the FEM modelling assumptions. Some programs are specially dedicated to the analysis of forging processes and have implemented methods (options) to assess the typical defects of metal flow (like laps, folds, underfilling) (Hawryluk \& Jakubik, 2016, Gronostajski et al., 2019). To diagnose, trace and investigate the metal flow imperfections the authors present the use of the following methods, such as undersurface flow lines, red dots, metal-tool contact fields or parametric distance to surface change in time.

The undersurface flow lines are drawn along the workpiece surface as closed loops and are deformed together with material particles of a workpiece (Biba $\&$ Stebunov, 2010). The basic function of undersurface lines is to identify surface flaws such as flow- 
through defects and shrinkage holes in the workpiece during forging.

In some cases of impression die forging, the finite element method does not allow to explicitly identify some defects in the finished forged pieces, which leads to using of additional criteria for evaluation of simulation results for improving their quality. In such situation software enables prediction of defects due to: minimum distance to surface or distance to contact, users postprocessing subroutine Gartfield (Gartvig, 2017). The minimum distance-to-surface method may be used to analyze metal flow defects related to draw the metal from the surface of the workpiece into the depths. The quality and accuracy of any field depends on the size of the finite elements. is computed after the main deformation process is simulated. The results of the use of subroutine Gartfield are calculated based on the tensile deformation in the direction normal to the surface of the deformed workpiece. It is assumed that in the area where such tensile deformations accumulate defects like crack or flowthrough defect appear. Scale values are limited by default from 0.3 to 1 based on experimental data. The values from 0.7 and above may indicate a defect on the surface of the forged element.

\section{FORGING DEFECTS}

The authors, based on their knowledge and experience, show new QForm functions and tools designed to enable immediate identification and repair of forging defects that have previously been difficult to spot with simulation software. The examples presented in this chapter are based on previous authors' work as well as on newly developed problems, using advanced calculation methods and defects identification.

\subsection{Healing of the internal discontinuities}

Closing and healing of the internal discontinuities in open-die forging are vital issue in manufacturing of heavy-weight forgings. These problems have been widely studied through decades now (Banaszek et al., 2003; Banaszek \& Stefanik, 2006; Chen et. al., 2013; Kakimoto et al., 2010; Zhang et al., 2012; Zhang et al., 2017). In this respect, computer simulation are of great importance, since they allow to estimate required amount or work required for closing the pores, as an aid for dimension-based coefficients used in forging practice. In referred work, in order to analyse the dependence of changes in metallurgical structure of $12 \mathrm{Mg}$ ingot (figure 1), experiments of forging the offsets from the ingot were carried out, with theoretical forging preworking coefficient defined for following diameters: G620 - 1.55, G470 - 2.69, G350 - 4.85 and G250 - 9.51 (Chyła et al., 2012).

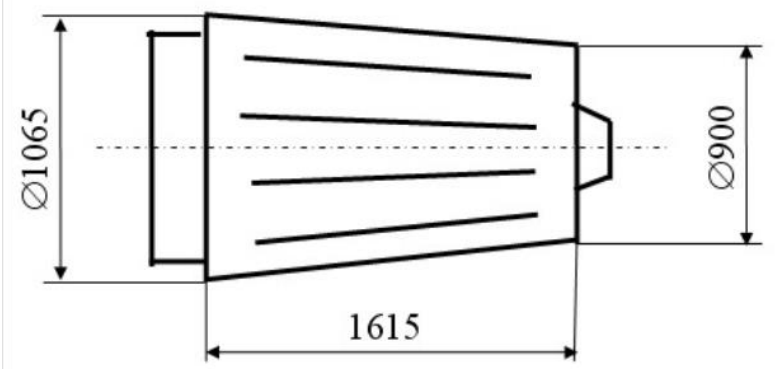

a)

b)

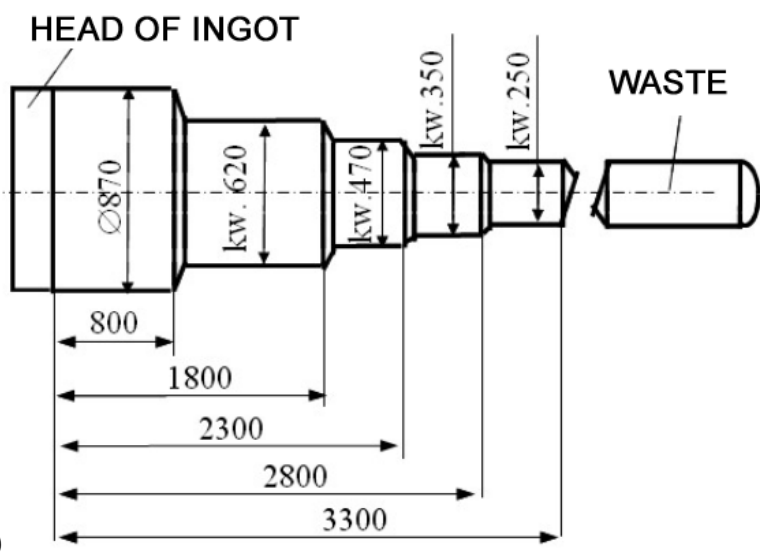

Fig. 1. Basic dimensions of ingot (a) and test forging (b) (Chyta et al., 2012).

Numerical calculation of multi-stroke cogging involved model of axial discontinuity of $50 \mathrm{~mm}$ diameter (figure 2a), which embraced the range of occurrence of piping detected with ultrasound method, marked A, B, C and D (figure 2c), as well as Baumann tests, indicating extent of the defects occurrence (figure 3a). After forging, unhealed pores were reduced to those originating in the head (W1 i W2 in figure $2 \mathrm{~d}$ ), whereas in the remaining part of the ingot no indications were detected. Consistent to industrial tests numerical simulation of the cogging process (figure $2 \mathrm{~b}$ ), allowed to determine the sequence of strokes, reductions and displacements (bites) values, formulating thus procedures for effective eradication of the internal defects in duty heavy forgings.

Combining the experimental work evaluated in Baumann tests, and numerical simulation it was concluded that amount of work 2.69 (defined based on dimension changes) is necessary for evident healing of the internal pores (Chyła et al., 2012). 
a)

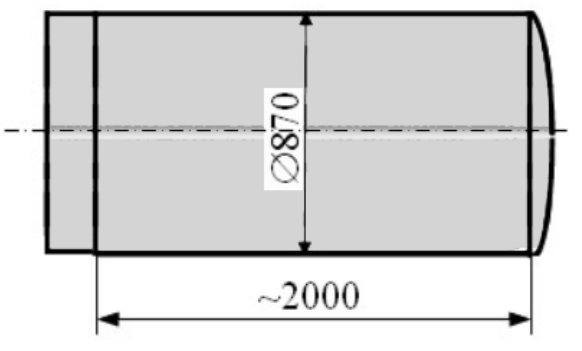

b)

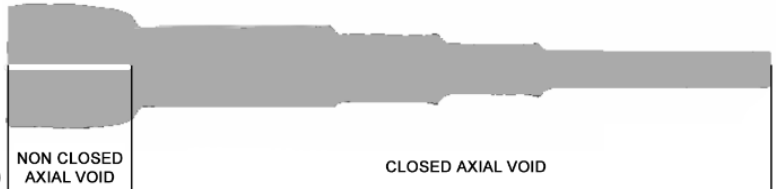

c)

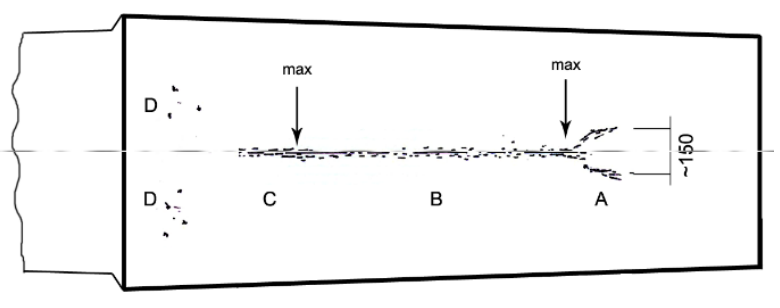

d)

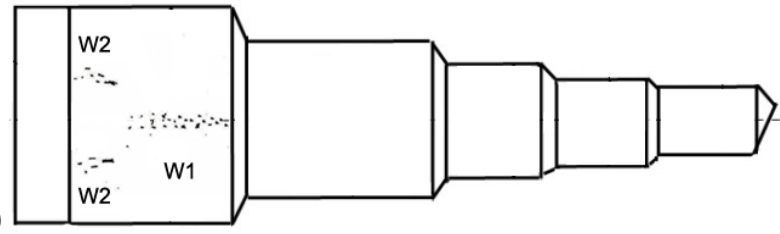

Fig. 2. Ingot with introduced axial void (a), places of axial void closing in test forging cross-section (b) and results of ultrasonic research for ingot (d) and test forging (c) (Chyta et al., 2012).

\subsection{Grain flow pattern estimation.}

One of the most crucial issues about soundness and quality of the forged parts is grain flow pattern.
Illustrating the history of metal flow it can indirectly indicate whether the metal flow was proper, or in other words, if the correct preform/impression was designed. Beyond this, grain flow is an indicator of grain pattern directionality, which enables assessment of mechanical properties in relation to expected service loading directions (Skubisz et al., 2008b; Bednarek et al., 2012; Biba et al., 2006). In computer simulation grain flow is represented by flow lines, which record history of displacement of a points array in bulk. Proper pattern of flow lines, conforming the outer periphery of a part lets assumption of smooth flow of the metal in cavity, as well as flow lines profile corresponding to macro-etched grain flow speaks for credibility of simulation of a forging process as such (figure 4) (Biba et al., 2001; Sińczak et al., 2007; Łukaszek-Sołek, 2014).

This feature is of importance in evaluation of mechanical testing results, allowing for proper selection of specimens in relation to grain flow direction. In the volume of forging are areas having substantial diversification of deformation. In figure 5 the examples of the results of the numerical calculation and physical modelling of the forging process of flange made of $300 \mathrm{M}$ steel at the temperature of $1000^{\circ} \mathrm{C}$ and $1100^{\circ} \mathrm{C}$ are shown (Bednarek et al., 2012), indicating variation of directionality of segregation-related bands at locations. Consideration of the properly estimated grain flow is the key issue in proper interpretation of the results and prediction of mechanical properties, e.g. impact strength.

a)

AXIS OF INGOT

SURFACE

b)

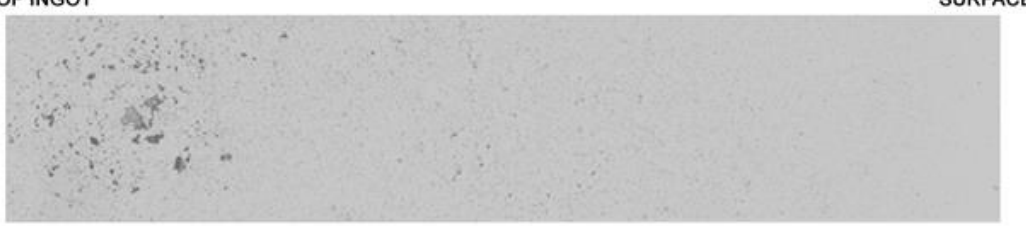

c)

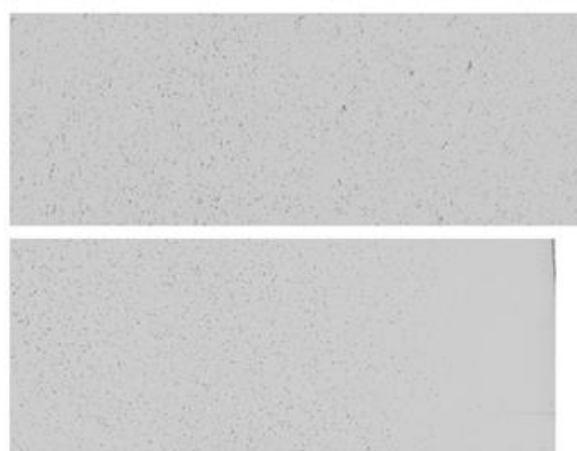

Fig. 3. Baumann test results of test forging with degree of forging 1 (a), 1.55 (b) and 2.69 (c) (Chyla et al., 2012). 


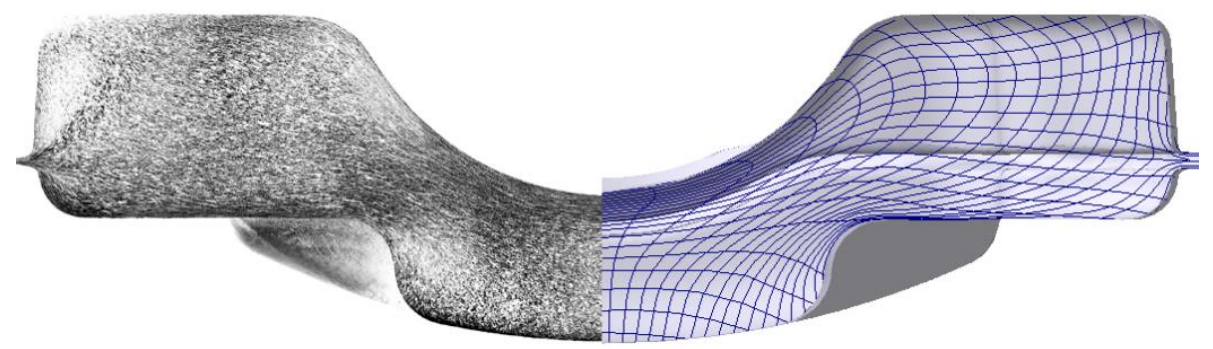

Fig. 4. Grain flow pattern (a) and numerically calculated flow lines (b) in longitudinal section of a contact tip (Eukaszek-Sotek, 2014).

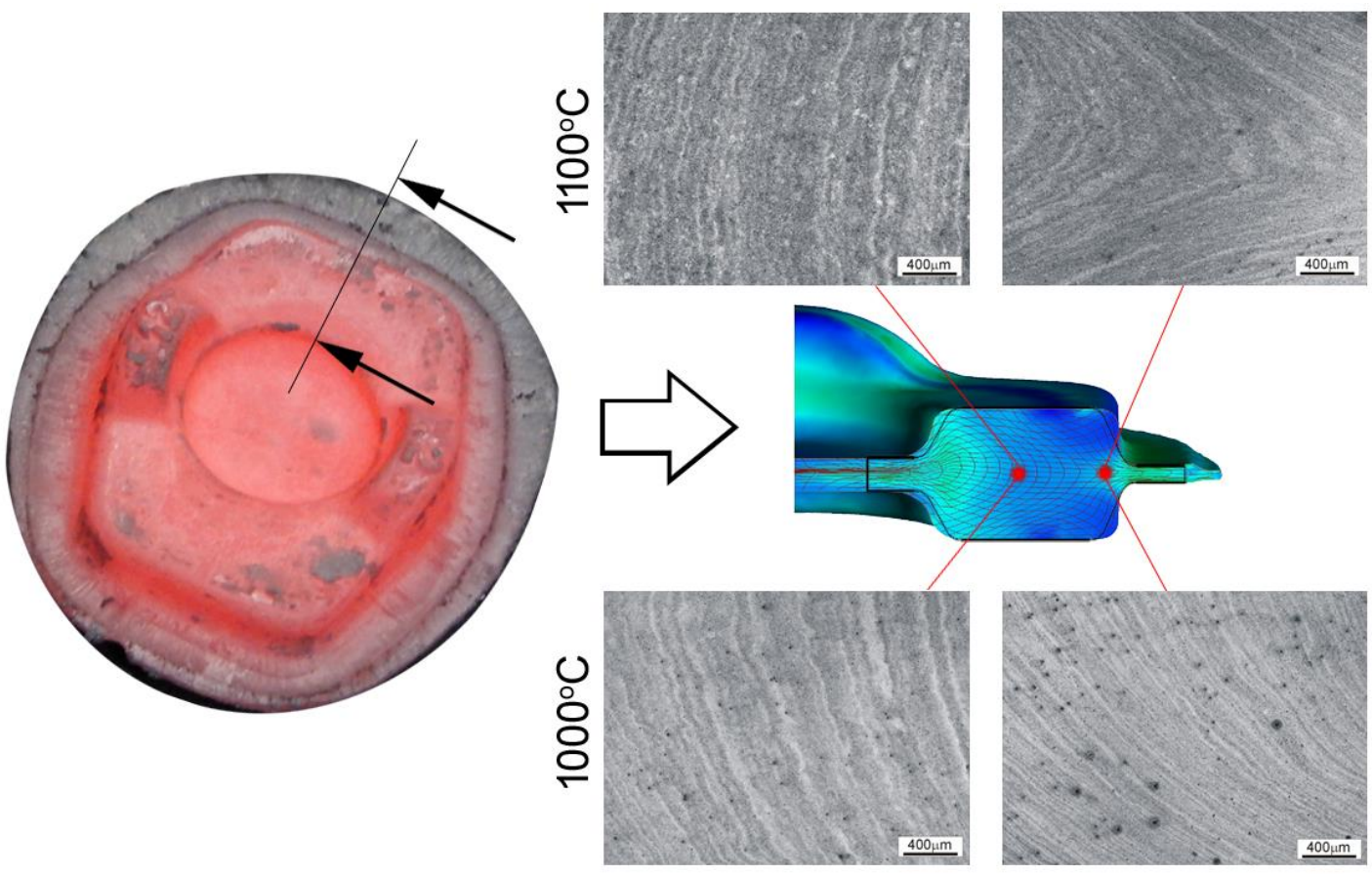

Fig. 5. Hammer forging of 300M collar forging - structure bending in cross section.

\subsection{Powder sinters compaction.}

To enable the use of FEM simulation for analysis of sintered powders, special model has been created, which makes it possible to take into consideration changes in density and correspondingly, changes in volumetric dimensions, implemented into QForm commercial code. The module is based on the theoretical assumptions by Oyane (Khoei, 2005). This capability of the program was tested in the study in analysis of aluminium powder compaction. The input material was $\mathrm{Al}$ powder with particles ranging $90 \div 560$ $\mu \mathrm{m}$ and averaged density $74.85 \pm 0.37 \%$. It was cold compacted in a heated up die-set. Then the compacts were placed in the die cavity heated to the assumed temperature $\left(400^{\circ} \mathrm{C}\right.$ or $\left.500^{\circ} \mathrm{C}\right)$ and held up for time period necessary for stabilization of the system, 300 s. Afterwards, the specimen was compressed under unit pressure $80 \mathrm{MPa}$ during 120s. Obtained sample is shown in figure 6 .
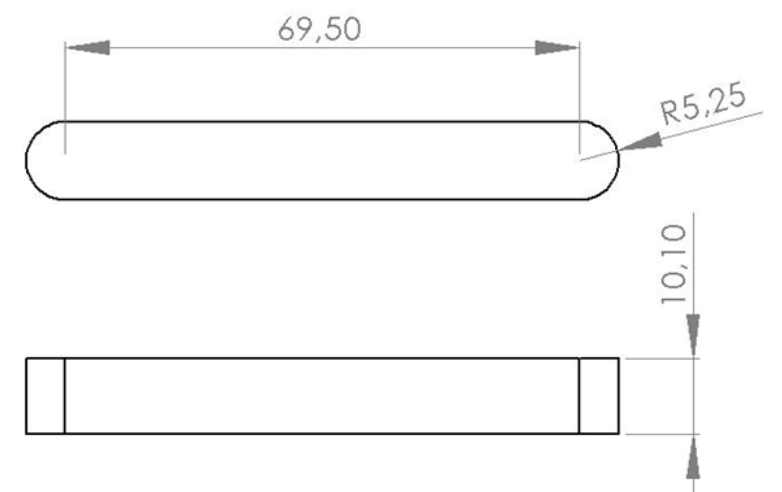

a)

b)

Fig. 6. Shape of aluminium sample after closed-die hot compacting (Wojtaszek \& Bednarek, 2011). 
Numerical computation of compaction allowed determination of relative density, including normal distribution histogram to be drawn, which was helpful in calculation of mean density (figure 7).

a)

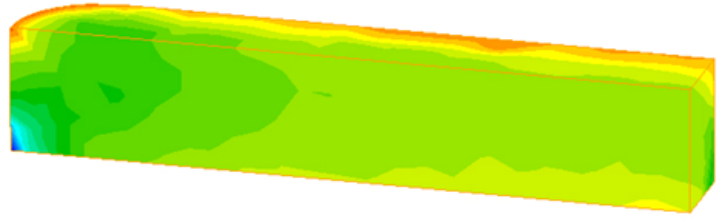

b)
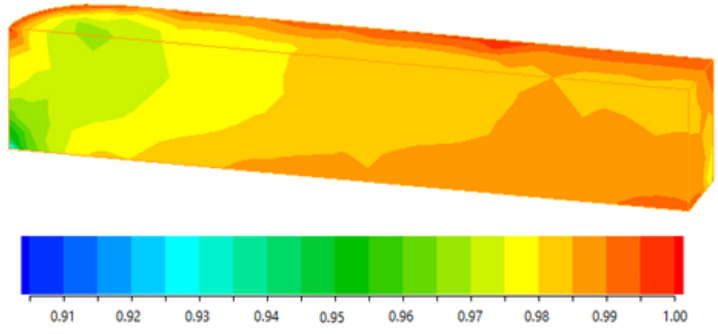

c)

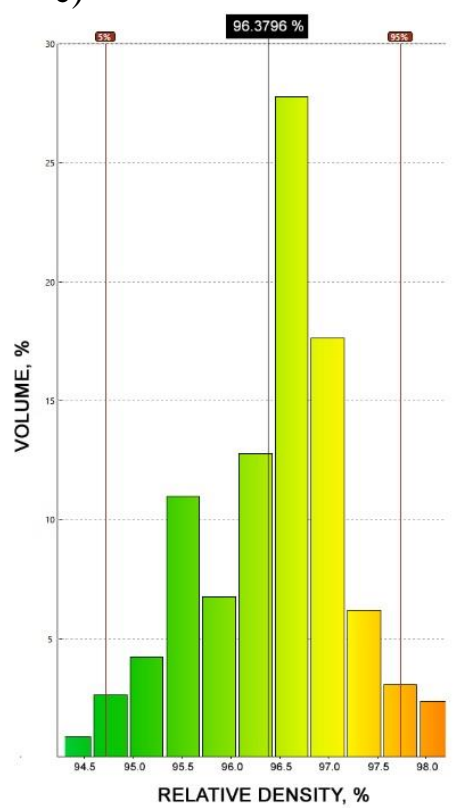

d)

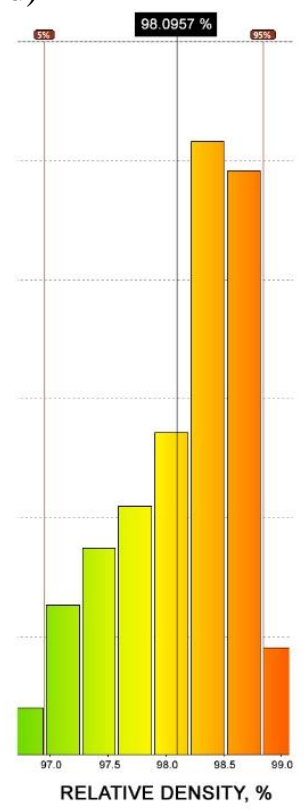

Fig. 7. Distribution of relative density and normal distribution histogram of relative density calculated for Al powder compaction in $400^{\circ} \mathrm{C}\left(a\right.$ and $c$ ) and $500^{\circ} \mathrm{C}(b$ and $d)$.

Experimental measurement with use of Archimedes method and those calculated numerically are compared in figure 8 with reference to initial density. The experimentally measured density level of specimen deformed at $400^{\circ} \mathrm{C}$ was $96.15 \pm 0,6 \%$, and that of $500^{\circ} \mathrm{C}, 97.82 \pm 0,31 \%$. Comparing these values with simulation results, $96.38 \%$ for $400^{\circ} \mathrm{C}$, and $98.1 \%$ for $500^{\circ} \mathrm{C}$ suggests impressive agreement, which gives credits for the use of the model in design of precision forging of sintered alloys.

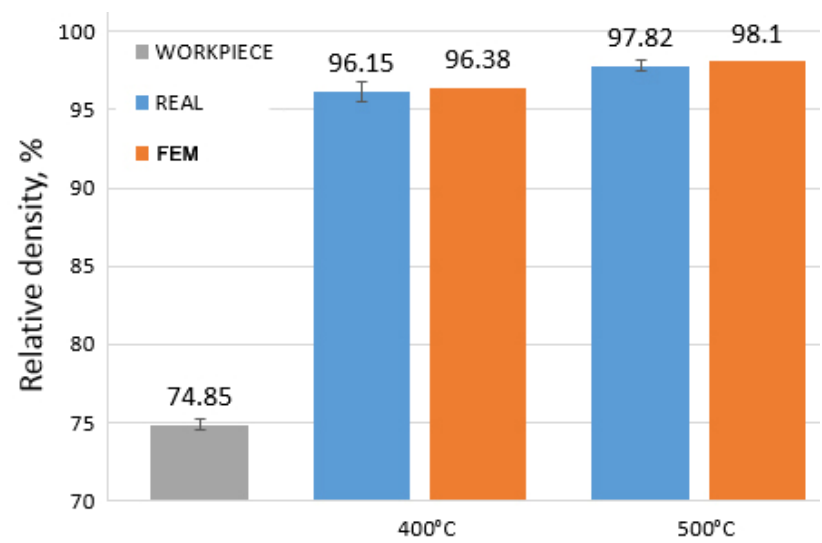

Fig. 8. Influence of temperature on the relative density of materials obtained by closed-die hot consolidation of aluminium powder compacts.

\subsection{Laps and folds.}

Given the design of new or modification of forging technology, it is better to understand and control the process in economic terms, as well as from a quality point of view, to avoid defects rather than scrapping defective parts during final inspection (Rathi \& Jakhade, 2014; Thorat \& Ligade, 2018). Below are the possibilities of simulation and prediction of metal flow defects (laps and folds) for forging having a compact structure and the different material processing degrees. The shape and also the dimension of the workpiece have a significant influence on the proper filling of the dies cavity too. Gao et al. (2019) has developed approach for the prediction of three typical types of folding defects in die forging by metamodelling techniques based on FE simulation results. Petrov et al. (2006) has investigated the occurrence of folding during the near-net shape forging of an aluminum part with an irregular shape and he applied QForm software for the numerical investigation. The forging showed in figure 9 is the representative example of forgings having complex shape with circular contour in the parting plane. One of the important problems in forging process is large material flow towards gutter. The metal is squeezed out of the upper die downwards to fill the die cavity and appear areas of difficulty flow. The forming is carried out by upsetting, then punching and extrusion. Finishing die impression is filled in the complex scheme of flow and it is possible to obtain the relatively high forging reduction ratio. At the same time a vertical flash is being formed. In the process of filling the central part of the forging, the metal vigorously flows from areas already filled towards the gutter (figure 9). It leads to a stagnant zone in the first collar of forging, espe- 
cially in lower die, dragging the surface material layers into the outside body of the forged part. Such improper material flow caused the curling of material in the first stage of forging, resulted in extensive lap formation (figure 10). In connection with that, it is possible that forging defects like folds will be formed.

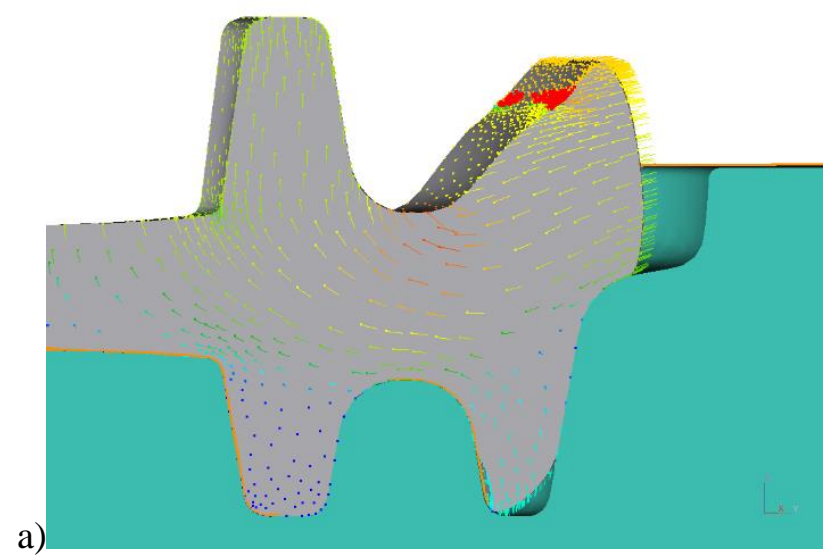

b)

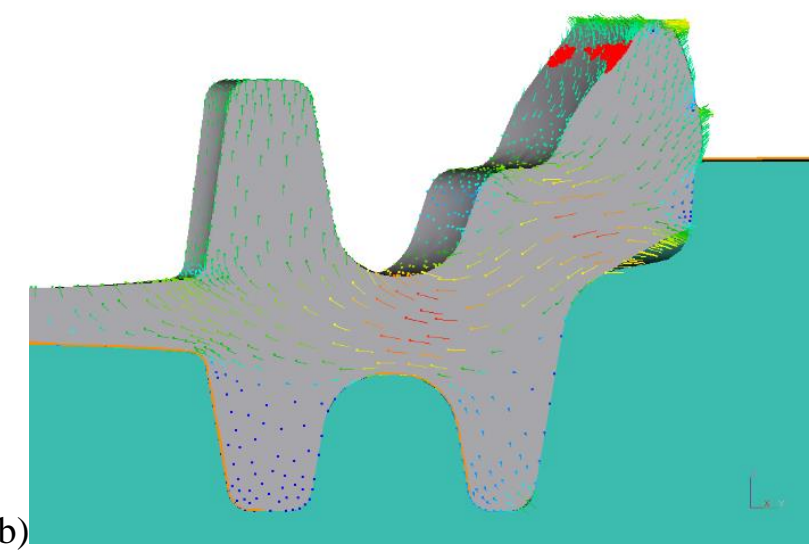

c)

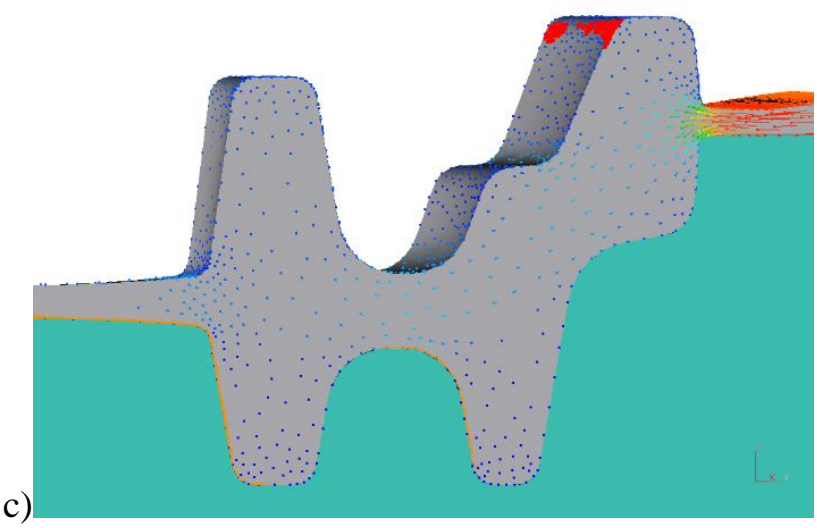

Fig. 9. Velocity vector of metal flow during characteristic stages of forging.

An analysis of simulation results shows the flowthrough defects not only laps but also the appearance and growth of folds revealed by the program function to detect such defects (figure 11). Flow-through defects are identified by undersurface lines appearing to be pulled into the volume of the workpiece. Furthermore such defects could be identified by option: minimum contact to surface and standard subroutine Garfield (on scale 0 means no defects and 1 means high risk of defects).

a)

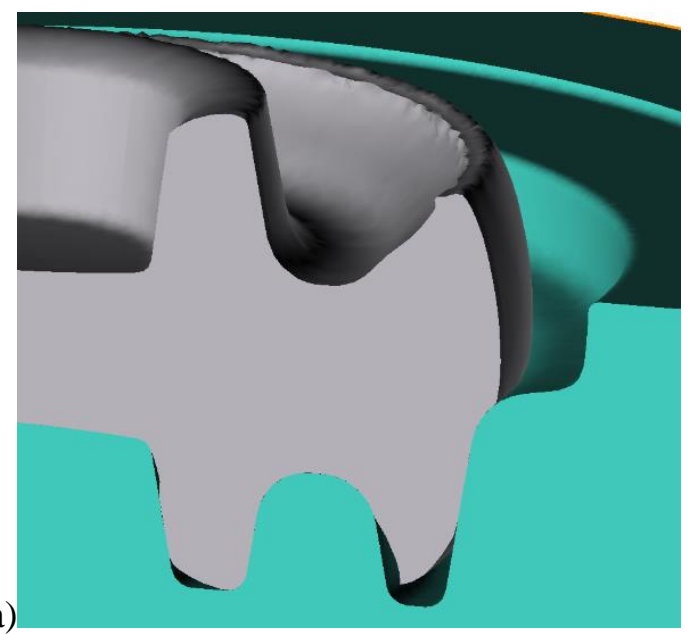

b)

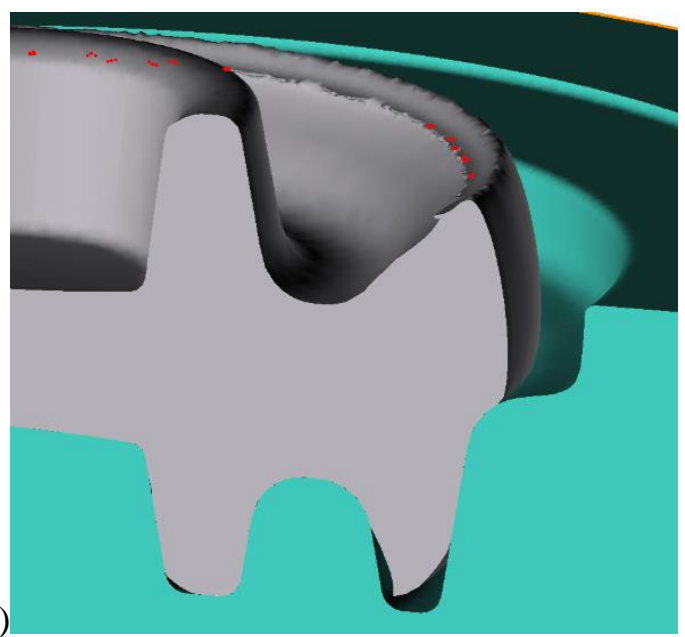

c)

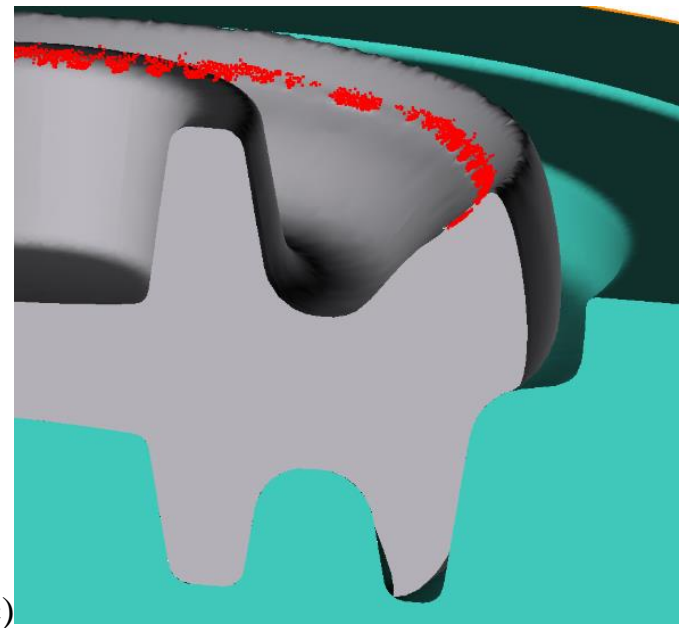

Fig. 10. Mechanism of lap formation. 
a)

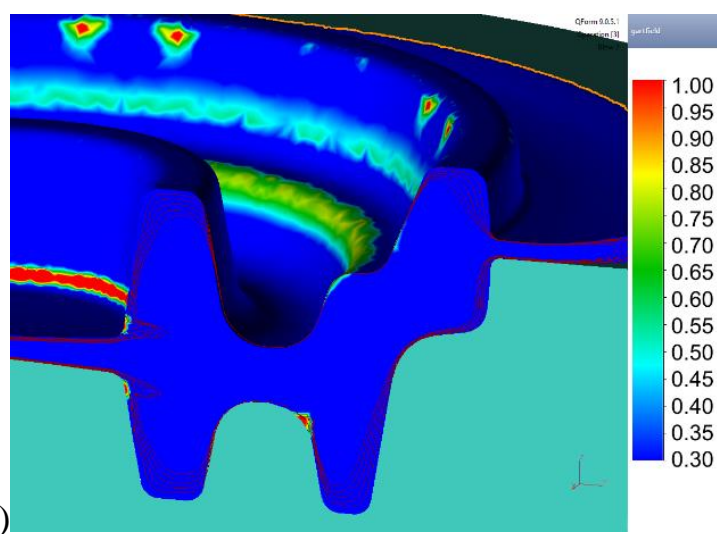

b)

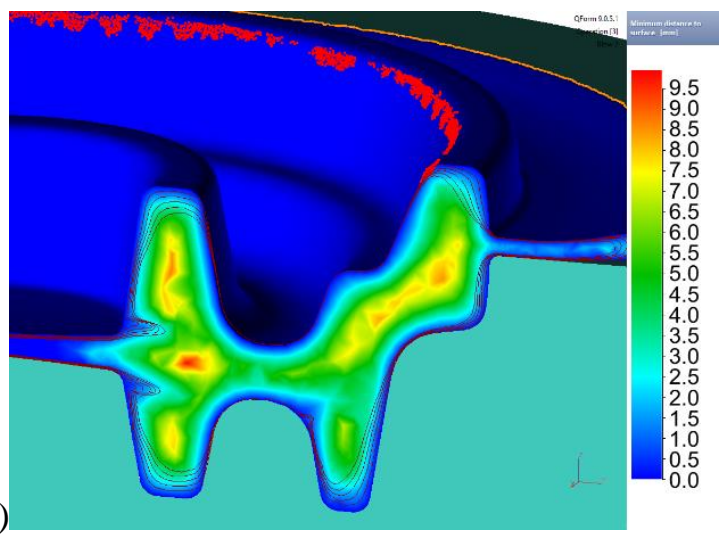

Fig. 11. Flow-through defects: a) Gartfield fields, b) undersurface lines and minimum distance to surface.

\subsection{Identification of different fracture mecha- nisms in open-die forging}

In the following part of paper the methodology of estimation of the risk of fracture appearance was presented. The analysis was based on numerical simulation with consideration of using subroutines implemented in LUA codes. The fracture criteria have been extensively studied for the last decades and there can be dozens of different formulas found in the literature, based on different concepts of plasticity and accounting to different thermo-mechanical parameters (Gouveia et al., 2000; Saanouni, 2008). Thanks to the analysis of open-die forging processes using fractures criteria it was possible to select the basic causes of cracking during forming.

The main assumption in numerical analysis was to include a Triaxiality Factor (TF) which allowed to define areas of tensile stress domination (Bjorkman et al., 2010). It is understood, that the concentration of tensile or shear stresses promotes cracking of the material. Thus the TF is defined as:

$$
T F=\frac{\left(\sigma_{1}+\sigma_{2}+\sigma_{3}\right)}{\sqrt{0,5\left(\left(\sigma_{1}-\sigma_{2}\right)^{2}+\left(\sigma_{2}-\sigma_{3}\right)^{2}+\left(\sigma_{3}-\sigma_{1}\right)^{2}\right)}}
$$

where: $\sigma_{1}, \sigma_{2}, \sigma_{3},-$ main stresses.
TF allows an identification of determine the areas of unfavourable stress state concentration was possible. Triaxiality Factor links together the values of principal stresses and it can be stated that when the equation result is close to 1 , the domination of tensile stress can be observed (Lisiecki et al., 2015). This analysis allowed the preliminary selection of the specimens' areas, where the risk of crack is high.

The purpose of the analysis was to determine of critical parameters of selected fracture criteria values: Cockcroft and Latham

$\int_{0}^{\bar{\varepsilon}_{f}} \sigma_{\theta} d \bar{\varepsilon}=C_{1}$

based on largest tensile stress $\sigma_{\theta}$.

Rice and Tracey

$\int_{0}^{\bar{\varepsilon}_{f}} \exp \left(\frac{3 \sigma_{m}}{2 \bar{\sigma}}\right) d \bar{\varepsilon}=C_{2}$

considered hydrostatic $\sigma_{m}$ and effective stress at the moment of crack initiation.

Freudenthal (4)

$\int_{0}^{\bar{\varepsilon}_{f}} \bar{\sigma} d \bar{\varepsilon}=C_{3}$

In equations (2), (3) and (4) $\bar{\sigma}$ is the effective stress, $\bar{\varepsilon}_{f}$ is the effective failure strain and $C_{1}, C_{2}, C_{3}$ are material constants.

These criteria are also discussed in (Gouveia et al., 2000; Saanouni, 2008; Lisiecki et al., 2015). The selected criteria do not take into account complex material constants (such as e.g. size of discontinuities), thus the risk of cracking can be quickly determined for any forging process. The results allowed for analysis of the risk of fracture taking into consideration the deformation limit.

The connection of the above assumptions gave the possibility of comprehensive analysis of the estimation of risk of fracture during open-die forging. For verification purposes, open-die forging processes in laboratory conditions were performed. The goal of this work was to induce controlled cracks in different part of samples. The selected samples with the marked cracks location are shown in the figure 12 .
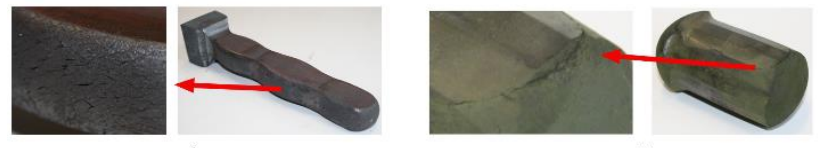
a) b)

Fig. 12. Location of cracks in samples after open-die forging in laboratory conditions. 
The methodology based on inclusion of three different fracture criteria connected with Triaxiality Factor in the numerical modelling gave the opportunity to identify various causes of material cracking during open-die forging. Figure 13 shows the identification of areas with increased risk of cracking during cogging operation. Depending on the change of process parameters, the risk area varies.

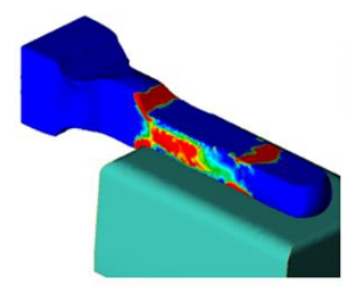

a)

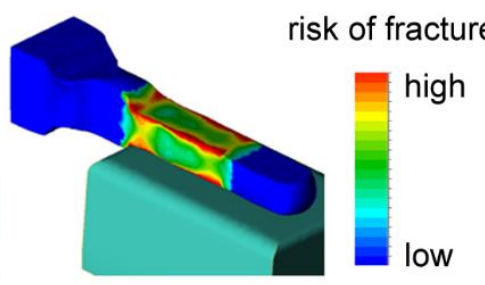

b)
Fig. 13. Location of cracks in samples after open-die forging in laboratory conditions.

One of the basic causes of fracture formation during open-die forging are laps on the surface. The performed tests show that the areas of appearance of the laps are also places with an increased risk of cracking, as shown in the figure 14a. Continuation of the process with laps leads to the appearance of surface fracture (figure $14 \mathrm{~b}$ ).

The presented results of open-die forging in laboratory conditions combined with computer simulation allowed to determine four different mechanisms of material cracking during this type of processes.
The main cause of damage is considered to be poorly selected process parameters. Too low forging temperature may lead to cracks in the side surface of the forging (figure 15a), the resulting laps may lead to surface (figure 15b) or edge cracks (figure 15c), while forging with large reduction ratio combined with low material temperature can be the cause of rupture (figure $15 \mathrm{~d})$.

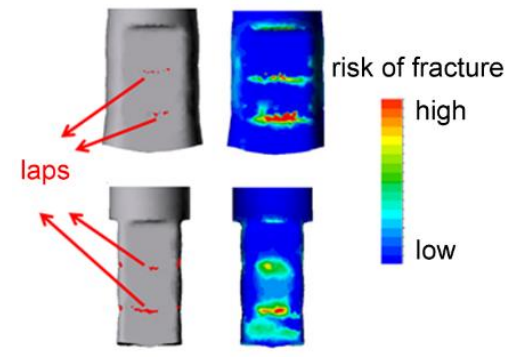

a)

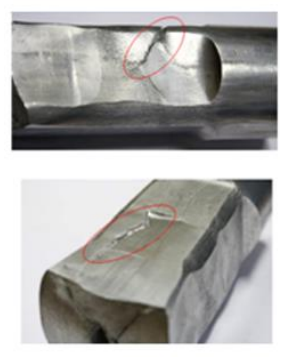

b)
Fig. 14. Comparison of laps and fractures areas (a), effects of forging with laps $(b)$.

Defects were identified by a combination of Triaxiality Factor and fracture criteria. The analysis showed that Cockcroft \& Latham criterion shows the highest consistency of results in the case of side surfaces cracks (figure 15a). Freudenthal criterion forecasts the defects shown on figures $15 \mathrm{~b}$ and $15 \mathrm{c}$. The defect in the form of rupture (figure 15d) is prognozed based on Rice \& Tracey criterion.
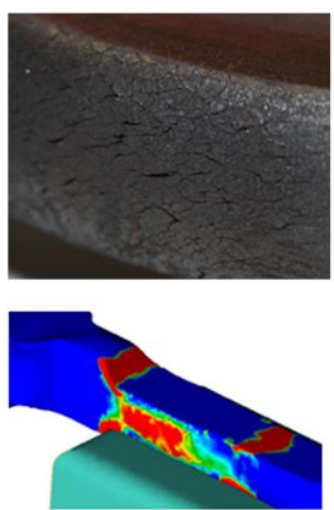

a)
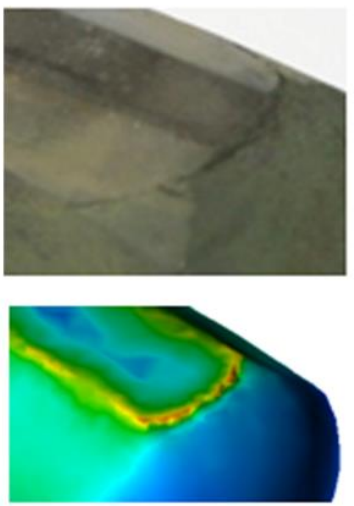

b)
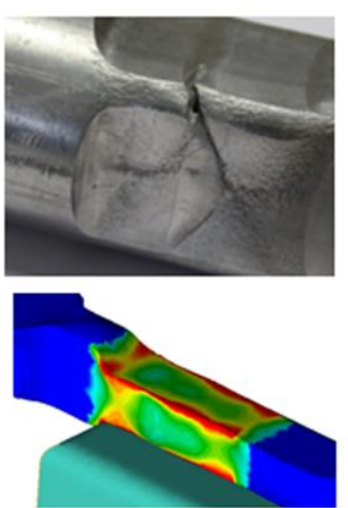

c)
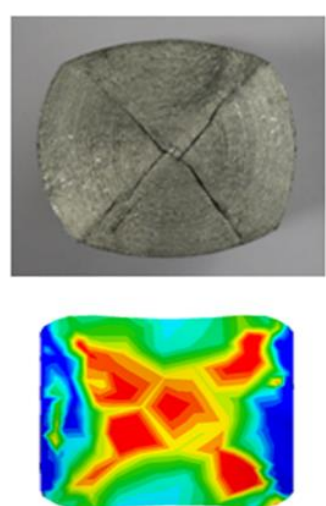

d)

risk of fracture

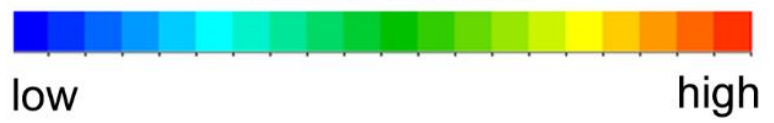

Fig. 15. Identified types of fractures during open-die forging: a) cracking of the side surfaces, b) cracking initiated by laps, c) lateral edge crack, d) rupture. 
Numerical simulation in QForm software, by using "user subroutine" scripts taking into account selected fracture models, allows determining the risk of fracture and its causes at the stage of design of the open-die forging process design of the open-die forging process.

\section{CONCLUSIONS}

The examples presented in the paper recapitulate the use of commercial code QFormVX for identification and analysis of metal flow defects in forged parts. It has been demonstrated that the numerical simulation of the forging processes, allowed to formulate the procedures for effective eradication of the internal defects in duty heavy forgings, allowed estimating grain flow pattern, to consider changes in density and changes in volumetric dimensions. Presented closeddie forging techniques analyze mechanisms of formation of the common defects encountered in forgings, such as, laps, flowthrough defects, underfilling

\section{ACKNOWLEDGMENTS}

The research project was financed by the Ministry of Science and Higher Education (AGH - research subsidy No. 16.16.110.663).

\section{REFERENCES}

Alimov, A., Zabelyan, D., Burlakov I., Korotkov I., Gladkov Y., 2018, Simulation of deformation behaviour and microstructure evolution during hot forging of TC11 titanium alloy, Proc. Conf. Superplasticity in Advanced Materials ICSAM 2018, Defect and Diffusion Forum, 385, 449-454.

Banaszek, G., Stefanik, A., Dyja, H., Berski, S., Janik, M., 2003, Modelowanie komputerowe i laboratoryjne procesu zamykania wad pochodzenia metalurgicznego we wlewkach podczas kucia swobodnego na gorąco, Rudy i Metale Nieżelazne, 10-11, 512-517 (in Polish).

Banaszek, G., Stefanik, A., 2006, Theoretical and laboratory modelling of the closure of metallurgical defects during forming of a forging, J. Mater. Process. Tech., 177, 238242.

Bednarek, S., Krawczyk, J., Bała, P., Łukaszek-Sołek, A., 2012, Forging of 300M steel collar, Proc. Conf. Metal Forming 2012, Steel Res. Int., spec. ed., 179-182.

Biba, N., Stebunov, S., 2010, QForm3D - cost effective simulation tool for metal forming technology, Proc. Conf. the Korean Society for Technology of Plasticity Conference, 15th Forging Symposium, 77-80.

Biba, N.V., Stebunov, S.A., Ovchinnikov, A.V., Shmelev, V. P., 2006, Experience in simulation for predicting the structure of die forgings, Met. Sci. Heat Treat., 48, 7-8.

Biba, N., Stebounov, S., Lishiny, A., 2001, Cost effective implementation of forging simulation, J. Mater. Process. Tech., $113,1,34-39$
Bjorkman, G. S., Ammerman, D., Snow, S., Morton, D. K., 2010, Strain-based acceptance criteria for spent fuel storage and transportation containments, U.S. NRC, 1-8.

Bramley, A.N., Mynors, D.J., 2000, The use of forging simulation tools, Mater. Des., 21, 279-286.

Chen, M.S., Lin, Y.C., 2013, Numerical simulation and experimental verification of void evolution inside large forgings during hot working, Int. J. Plasticity, 49, 53-70.

Chyła, P., Kowalski, J., Bednarek, S., Łukaszek-Sołek, A., Sińczak, J., 2012, Zamykanie wewnętrznych nieciągłości w procesie kucia wlewków, przeznaczonych na duże odkuwki swobodnie kute, Hutnik Wiadomości Hutnicze, 79, 4, 219 224 (in Polish).

Ellinghausen, T., 2013, The revolution of simulation software development, FORGING, 16-18.

Gartvig, A., 2017, New method of material flow defects prediction at metal forming simulation, presented at QForm Forum, Berlin, http://qform3d.com/files_com/docs/Program_QForm\%20Forum.Berlin_6.09.2017.pdf.

Gao, P.F., Fei, M.Y., Yan, X.G., Wang, S.B., Li, Y.K., Xing, L., Wei, K., Zhan, M., Zhou, Z.T., Keyim, Z., 2019, Prediction of the folding defect in die forging: A versatile approach for three typical types of folding defects, J. Manuf. Process., 39, 181-191.

Gouveia, B.P.P.A., Rodrigues, J.M.C., Martins, P.A.F., 2000, Ductile fracture in metalworking: experimental and theoretical research, J. Mater. Process. Tech., 101, 52-63.

Gronostajski, Z., Pater, Z., Madej, L., Gontarz, A., Lisiecki, L., Łukaszek-Sołek, A., 2019, Recent development trends in metal forming, Arch. Civ. Mech. Eng., 19, 3, 898-941.

Guo, Z., Lasne, P., Saunders, N., Schillé, J.-P., 2018, Introduction of materials modelling into metal forming simulation, Proc. Conf. Metal Forming 2018, Proc. Manufacturing, 15, 372380 .

Hawryluk, M., Jakubik, J., 2016, Analysis of forging defects for selected industrial die forging processes, Eng. Fail. Anal., 59, 396-409.

Hawryluk, M., Gronostajski, Z., Kaszuba, M., Krawczyk, J., Widomski, P., Ziemba, J., Zwierzchowski, M., Janik, M., 2018, Wear mechanisms analysis of dies used in the process of hot forging a valve made of high nickel steel, Arch. Metall. Mater., 63, 4, 1963-1974.

He, H., Huang, S., Yi, Y., Guo, W., 2017, Simulation and experimental research on isothermal forging with semi-closed die and multi-stage-change speed of large AZ80 magnesium alloy support beam, J. Mater. Process. Tech., 246, 198-204.

Kakimoto, H., Arikawaa, T., Takahashib Y., Tanakac, T., Imaida, Y., 2010, Development of forging process design to close internal voids, J. Mater. Process. Tech., 210, 415-422.

Khoei, A.R., 2005, Computational Plasticity in Powder Forming Processes, Elsevier Science, San Diego, CA

Lisiecki, Ł., Skubisz, P., 2016, Elaboration of ductile fracture criteria based on punching forgeability test, Computer Methods in Materials Science, 16, 1, 382-394.

Lisiecki, Ł., Skubisz, P., 2015, Analysis of the impression-die forging process of hard-to-deformation magnesium alloys with regard to fracture occurrence, Rudy $i$ Metale Nieżelazne Recykling, 12, 664-668.

Lisiecki, Ł., Skubisz, P., Karwan, J., 2015, Prediction and investigation of fracture initiation in warm forging of martensitic stainless steel with aid of FEM simulation, Computer Methods in Materials Science, 15, 2, 346-352. 
Łukaszek-Sołek, A., 2014, Effect of technical quality of thermomechanical die forging of AA2099 alloy, Arch. Metall. Mater., 59, 997-1003.

Metals Handbook: Vol. 14, Forming and Forging, 1988, 9. Ed. Metals Park (Ohio): American Soc. for Metals.

Pérez, M., 2018, Microstructural evolution of Nimonic 80a during hot forging under nonisothermal conditions of screw press, J. Mater. Process. Tech., 252, 45-57.

Petrov, M.A., Petrov, A.N. Petrov, P.A., 2016, Numerical investigation of the material behaviour during compression tests for samples with rough surfaces represented in different geometry scale factors, Key Eng. Mater., 716, 736-752.

Petrov, P, Perfilov, V, Stebunov, S., 2006, Prevention of lap formation in near net shape isothermal forging technology of part of irregular shape made of aluminium alloy A92618, $J$. Mater. Process. Technol., 177 (1-3), 218-23.

Rathi, M.G., Jakhade, N.A., 2014, An overview of forging processes with their defects, Int. J. Scientific and Research Publications, 4, 6, 1-6.

Saad, M., Akhtar, S., Srivastava, M., Chaurasia, J., 2018, Role of simulation in metal forming processes, ICMPC 2018, Materials Today: Proceedings, 5, 19576-19585.

Saanouni, K., 2008, On the numerical prediction of the ductile fracture in metal forming, Eng. Frac. Mech., 75, 3545-3559.

Sińczak, J., Łukaszek-Sołek, A., Skubisz, P., Bednarek, S., 2007, Impression-die forging of flange with utilization of thermomechanical treatment, Hutnik - Wiadomości Hutnicze, 74 187-191 (in Polish).

Skripalenko, M.M., Romantsev, B. A., Bazhenov, V. E., Tran, B.H., 2019, Computer simulation of Mannesmann piercing of aluminium alloy ingots, Russ. J Non-Ferr. Met., 60, 1 , 27-34

Skubisz, P., Łukaszek-Sołek, A., Kowalski, J., Sińczak, J., 2008a, Closing the internal discontinuities of ingots in open die forging, Proc. Conf. Metal Forming 2008, Steel Res. Int., spec. issue, 79, 1, 555-562.

Skubisz, P., Łukaszek-Sołek, A., Sińczak, J., Bednarek, S., 2008b, Drop forging of HSLA steel with application of thermomechanical treatment, Arch. Civ. Mech. Eng., 8, 4, 93102.

Skubisz, P., Krawczyk, J., Sińczak, J., 2012, Tool life enhancement in warm forging of $\mathrm{CV}$ joint with utilization of the divided flow method, Proc. Conf. Metal Forming 2012, Steel Res. Int., spec. issue, 235-238.

Stebunov, S., Biba, N., Vlasov, A., Maximov, A., 2011, Thermally and mechanically coupled simulation of metal forming processes, Proc. Int. Conf. Technology of Plasticity, Aachen, 171-175.

Thorat, M.L., Ligade, R.R., 2018, Review on defects in hot forging process - investigation, Int. J. Sustainable Development Research, 3, 4, 34-42.

Wojtaszek, M., Bednarek, S., 2011, Application of FEM simulation to numerical analysis of closed-die hot compacting of aluminum powder compacts, Rudy i Metale Nieżelazne, 6 , 348-353.

Vlasov, A., Biba, N., Stebunov, S., 2016, Elastic-plastic thermomechanical fatigue analysis of forging dies, Key Eng. Mater., 716, 667-676.

Zhang, X., Ma, F., Ma, K., Li, X., 2012, Multi-scale analysis of void closure for heavy ingot hot forging, Mod. Appl. Sci., 6, $10,15-25$
Zhang, L., Shen, W., Zhang, C., Xu, Q., Cui, Y., 2017, Numerical simulation of different types of voids closure in large continuous casting billet during multi-pass stretching process, Procedia Eng., 207, 532-537.

\section{NUMERYCZNA ANALIZY WYBRANYCH DEFEKTÓW W PROCESACH KUCIA}

\section{Streszczenie}

Wysokie wymagania stawiane przez klientów oraz potrzeba obniżenia kosztów produkcji przy jednoczesnym zachowaniu wysokiej jakości produktów powodują konieczność uwzględnienia specjalnych modeli i kryteriów w analizie numerycznej procesów kucia. Najnowsze podejścia oferowane przez producentów komercyjnego oprogramowania nie obejmują kompleksowej analizy wad. W wielu przypadkach konieczne jest uwzględnienie podprogramów stworzonych przez użytkownika i poświęconych konkretnym operacjom kucia. Interdyscyplinarna wiedza pozwala wybrać odpowiednią technikę prognozowania defektów typową dla analizowanego procesu kucia. Głównym celem artykułu przeglądowego jest pokazanie najnowszych narzędzi, ich modyfikacji i rozszerzeń do przewidywania defektów często obserwowanych w procesie przemysłowym kucia z wykorzystaniem modelowania MES. Metodologia badań polegała na połączeniu modelowania numerycznego, testów laboratoryjnych i analizy procesów przemysłowych.

Received: November 27, 2019. Received in a revised form: December 12, 2019. Accepted: December 16, 2019. 